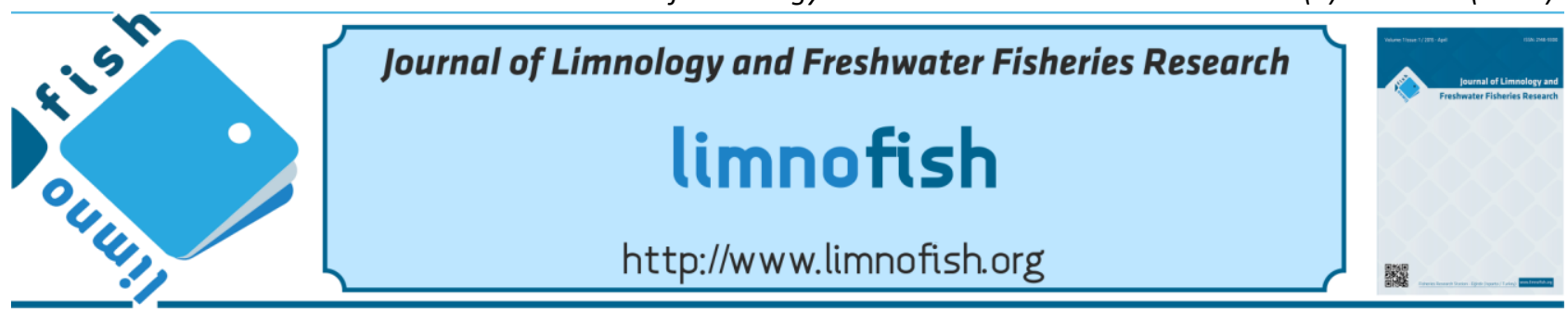

\title{
Adsorption Process of Ammonium by Natural Zeolite (Clinoptilolite) from Aqueous Solution for Aquaculture Application
}

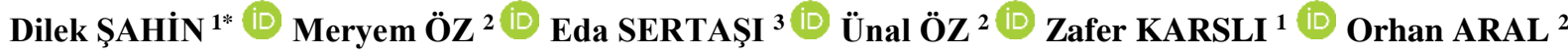 \\ ${ }^{1}$ Underwater Technology Programme, Vocational School, Sinop University, 57000 Sinop, Turkey \\ ${ }^{2}$ Fisheries Faculty, Sinop University, 57000 Sinop, Turkey \\ ${ }^{3}$ Environmental Health Programme, Vocational School of Health Services, Sinop University, 57000 Sinop, Turkey
}

\section{A B STRACT}

Ammonia is an important nutrient in primary production, but high ammonia concentration is directly or indirectly toxic to many species of aquatic organisms. Ammonia and other toxic metabolites can be managed by adsorption and ion exchange. Zeolite is naturally occurring structured, aluminosilicate with high cation exchange and ion adsorption capacity. The purpose of this study was to determine the effects of zeolite on the ammonium adsorption at different particle sizes $(0.075 \mathrm{~mm}, 3-5 \mathrm{~mm})$ and adsorbent dosages $(5 \mathrm{~g} / \mathrm{l}, 10 \mathrm{~g} / \mathrm{l}, 15 \mathrm{~g} / \mathrm{l})$ from aquatic solution. This research was conducted by trial groups with 3 repetitions during $330 \mathrm{~min}$. Water temperature, $\mathrm{pH}$, dissolved oxygen and ammonium values were measured during the trial period at regular intervals. Depending on the relevant literature, TAN (Total Ammonium Nitrogen) and adsorption efficiency were also calculated. This study values showed a decrease of TAN concentration in all the groups with increasing contact time. For different particle size and adsorbent dosage of zeolite, the best efficiency $(44.1 \%)$ is determined at added 15 $\mathrm{g} / 1$ and $0.075 \mathrm{~mm}$ zeolite group $(\mathrm{P}<0.05)$. Our results revealed that zeolite might be used for ammonia removal in aquaculture.
ARTICLE INFO

\section{RESEARCH ARTICLE}

$\begin{array}{lll}\text { Received } & : 03.05 .2018 \\ \text { Revised } & : 12.12 .2018 \\ \text { Accepted } & : 15.01 .2019 \\ \text { Published } & : 27.08 .2019\end{array}$

DOI:10.17216/LimnoFish.420380

* CORRESPONDING AUTHOR

dsahin@sinop.edu.tr

Phone : +90 5334834093

Keywords: Clinoptilolite, adsorption, ammonium, aquaculture

\section{Su Ürünlerinde Doğal Zeolit (Klinoptilolit) ile Amonyum Adsorpsiyonu}

Öz: Amonyak, birincil üretimde önemli bir besin maddesidir, ancak yüksek amonyak konsantrasyonu, birçok sucul organizma türüne doğrudan veya dolaylı olarak toksiktir. Amonyak ve diğer toksik metabolitler adsorpsiyon ve iyon değişimi ile yönetilebilir. Zeolit doğal olarak oluşan, yüksek katyon değişimi ve iyon adsorpsiyon kapasitesine sahip bir alüminosilikattır. Bu çalışmanın amac1, farklı partikül büyüklüğü $(0,075 \mathrm{~mm}, 3-5 \mathrm{~mm})$ ve adsorbant miktarına $(5 \mathrm{~g} / 1,10 \mathrm{~g} / \mathrm{l}, 15 \mathrm{~g} / \mathrm{l})$ bağlı olarak zeolit ile sucul ortamdan amonyum adsorpsiyonunun sağlanmasıdır. Araştırma, 3 tekerrürlü deneme grupları üzerinden 330 dakika boyunca yürütülmüştür. Deneme süresi boyunca, düzenli aralıklarla su sıcaklığı, pH, çözünmüş oksijen ve amonyum değerleri ölçülmüş, TAN (Toplam Amonyum Azotu) ve adsorpsiyon verimi ilgili literatüre bağlı olarak hesaplanmıştır. Çalışma değerleri artan temas süresi ile tüm gruplarda TAN konsantrasyonunun azaldığını göstermiştir. Zeolitin farklı partikül büyüklüğü ve adsorbant miktarı için en iyi verim $(\% 44,1) \quad 15 \mathrm{~g} / 1$ ve $0,075 \mathrm{~mm}$ zeolit grubunda belirlenmiştir $(\mathrm{P}<0,05)$. Sonuç olarak, zeolitin su ürünleri yetiştiriciliğinde amonyak giderimi için kullanılabileceği belirlenmiştir.

Anahtar Kelimeler: Klinoptilolit, adsorpsiyon, amonyum, su ürünleri

\section{How to Cite}

Şahin D, Öz M, Sertaşı E, Öz Ü, Karslı Z, Aral O. 2019. Adsorption Process of Ammonium by Natural Zeolite (Clinoptilolite) from Aqueous Solution for Aquaculture Application. LimnoFish. 5(2): 136-141. doi: 10.17216/LimnoFish.420380

\section{Introduction}

Provision of water quality for aquarium and recirculating aquaculture systems is a necessary process. One of the most important water parameters to be controlled for aquaculture is nitrogen compounds. In water, it creates inorganic compounds, mainly nitrate, nitrite, and ammonium ions. Nitrogen compounds are essential for the continuity of living organisms because nitrogen is one of the basic building blocks of living organisms. On the other hand, the presence of excessive amounts of nitrogen ions in different forms causes adverse effects on the ecosystem, as a result, damage or even kill the health of human and aquatic organisms (Gierak and Lazarska 2017). 
The fish produce nitrogen wastes by catabolism of amino acids. Nitrogen assimilation is important for fish health and profitability of production (Oluwaseyi 2016). Ammonia exists in water in two forms (un-ionized ammonia $\mathrm{NH}_{3}$ and ionized ammonium $\mathrm{NH}_{4}{ }^{+}$), especially ammonia $\left(\mathrm{NH}_{3}\right)$ is highly toxic to fish. Common concentrations of $\mathrm{NH}_{4}{ }^{+}$in aquaculture are $1-5 \mathrm{mg} / \mathrm{l} . \mathrm{NH}_{4}{ }^{+}$concentrations in aquaculture water are significantly lower than in municipal water (Jorgersen 2002).

Until now, the basis methods used to remove ammonium from wastewater are chemical, biological and physical treatment (Bock 2016). A lot of literatures about ammonium removal with adsorption were focused on natural minerals, due to their high safety, good adsorption capacity, and costeffectiveness. In addition, natural adsorbents are harmless to fish that can be used for treatment of aquaculture (Öz et al. 2010; Ghiasi and Jasour 2012).

Adsorption is the period in which molecules from solution accumulate on the external or/and internal surface of the porous solid (Kammerer et al. 2011). For this process different natural materials could be selected as zeolite, bentonite, barbecue bamboo charcoal, fly ash, sepiolite, fruit waste etc. In this study, we used zeolite which is a kind of natural mineral because of its cheaper cost and higher selectivity for ammonium removal.

Zeolites are crystallized hydrated aluminum silicates with a framework comprising pores coated by water and alkali and alkaline earth cations (Mazeikiene et al. 2008). One of the zeolites that have a high affinity for ammonia is clinoptilolite (Nicolae et al. 2017). Clinoptilolite ([AlSi $\left.{ }_{5} \mathrm{O}_{12}\right]_{2}\left(\mathrm{~K}_{2}, \mathrm{Na}_{2}, \mathrm{Ca}\right)$ $\left.\left(\mathrm{H}_{2} \mathrm{O}\right)_{8}\right)$ is a natural zeolite species. Because of its ammonium-ion selectivity is a suitable material for ammonium removal at high and low levels of temperatures in wastewater (Inglezakis 2005; Karadağ et al. 2006).

In freshwater for ammonium adsorption process, $\mathrm{pH}$ and water temperature are two important parameters. For ammonia adsorption aquaculture applications, optimum removed results are obtained between approximately $6-8.5 \mathrm{pH}$ and $10-27^{\circ} \mathrm{C}$ values (Jorgensen 2002; Iskander et al. 2014; Ismadji et al. 2016). Also, the influence of experimental conditions like; $\mathrm{pH}$, adsorbent dosage, contact time, particle size, agitation speed, and initial concentration were changed trial results (Aydin Temel and Kuleyin 2016).

In this study, it was aimed to determine the effects of zeolite on the ammonium adsorption at different dosage and particle size of adsorbent at same $\mathrm{pH}$, temperature, initial concentration and contact time without agitation.

\section{Material and Methods}

Natural zeolite (clinoptilolite) which was used in the present study proved that zeolite was an excellent adsorbent for ammonium removal from wastewater. Zeolite was taken from the Rota Mining Company in Manisa-Gördes in Western Anatolia. Chemical composition from manufacturer label of clinoptilolite were given in Table 1.

Table 1. Chemical composition of clinoptilolite that using in study

\begin{tabular}{cc}
\hline Oxide component & $\begin{array}{c}\% \text { (percentage by weight) } \\
\text { for Clinoptilolite }\end{array}$ \\
\hline $\mathrm{SiO}_{2}$ & 61.28 \\
$\mathrm{Al}_{2} \mathrm{O}_{3}$ & 17.79 \\
$\mathrm{Fe}_{2} \mathrm{O}_{3}$ & 3.01 \\
$\mathrm{CaO}$ & 4.54 \\
$\mathrm{Na}_{2} \mathrm{O}$ & 2.70 \\
$\mathrm{MgO}$ & 2.10 \\
$\mathrm{~K}_{2} \mathrm{O}$ & 1.24 \\
\hline
\end{tabular}

Ammonium chloride stock solution (1000 mg/l) was prepared by dissolving $\mathrm{NH}_{4} \mathrm{Cl}$ in deionized water. Solutions in using concentration was obtained was prepared by adding appropriate amounts of $\mathrm{NH}_{4} \mathrm{Cl}$ stock solution of deionized water to obtain an ion range of concentration varying from $11.7 \mathrm{mg} / \mathrm{l}$ (Saltalı et al. 2007). Experimental groups were prepared by adding 2 liter of tap water in this research and trial groups with 3 repetitions were created for three different adsorbent dosages $(5,10,15 \mathrm{~g} / \mathrm{l})$ and two particle sizes $(0.075,3-5 \mathrm{~mm})$ (Saltal1 et al. 2007; Mazeikiene et al. 2008; Öz et al. 2015; Aydın Temel and Kuleyin 2016) (Figure 1).

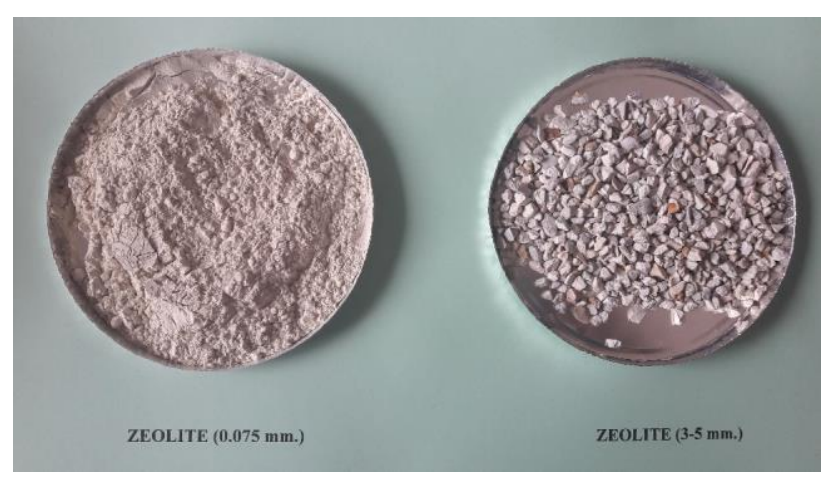

Figure 1. Experimental materials

Clinoptilolite (3-5 mm) was obtained from natural form and then experiment materials were washed in tap water until the turbidity was removed and dried at $105{ }^{\circ} \mathrm{C}$ (Mazeikiene et al. 2008). At a controlled room temperature; aeration, heating, lighting and agitation procedures were not applied during the trial period. Water temperature, $\mathrm{pH}$, dissolved oxygen and $\mathrm{NH}_{4}{ }^{+}$values were measured during the trial period. Water parameters were tested by YSI Professional Series Water Quality 
Instruments (Model: PRO PLUS) hand and field measurement units (Jorgensen 2002). This study was carried out with suitable water conditions for aquaculture and electrode method where serial and practical measurements can be made in the field and in the laboratory. Prajapati (2014) reported that, when compared Nessler method with the conventional electrode method, the two measurement methods in the study gave very close values and were reliable. Electrode method was preferred in this study because it is a method that can be easily, quickly, reliable and many measurements at short period obtained data of aquaculture.

The $\mathrm{NH}_{4}{ }^{+}$removal efficiency (\%) for the trial groups was calculated by using the following equations (Alshameri et al. 2017):

Removal efficiency $(\%)=\frac{C_{0-C_{e}}}{C_{0}} * 100$; where $\mathrm{C}_{0}$ is the initial ammonium concentration $(\mathrm{mg} / \mathrm{l}), \mathrm{C}_{\mathrm{e}}$ is the equilibrium ammonium concentration $(\mathrm{mg} / \mathrm{l})$.

During the study, $\mathrm{NH}_{3}$ and TAN levels were calculated from $\mathrm{NH}_{4}{ }^{+}$, water temperature and $\mathrm{pH}$ values (EPA 1999; Emerson et al. 1975; Chow et al. 1997). The calculation of the ammonium concentration was given below:

The dissociation constant, $\mathrm{K}_{\mathrm{a}}$, of ammonium ion was expressed as

$$
K_{a}=\frac{\left[\mathrm{NH}_{3}\right]\left[\mathrm{H}^{+}\right]}{\left[\mathrm{NH}_{4}^{+}\right]}
$$

Eq (1) can be further arranged as

$$
\frac{\left[\mathrm{NH}_{3}\right]}{\left[\mathrm{NH}_{4}^{+}\right]}=\frac{\mathrm{K}_{a}}{\left[\mathrm{H}^{+}\right]}
$$

Thus, the relationship between ammonia and ammonium concentrations may be described by

$$
\log _{10} \frac{\left[\mathrm{NH}_{3}\right]}{\left[\mathrm{NH}_{4}^{+}\right]}=p H-p K_{a}
$$

$\mathrm{pK}_{\mathrm{a}}$ varies with solution temperature. This temperature dependence is given by Emerson et al. (1975). As follows:

$$
p K_{a}=0.09018+\frac{2729.92}{(273.2+T)}
$$

Where $T$ is the solution temperature in ${ }^{\circ} \mathrm{C}$. Also; $\left[\mathrm{NH}_{4}^{+}\right]=\left[\mathrm{NH}_{3}\right]_{\mathrm{T}}-\left[\mathrm{NH}_{3}\right](5)$ forms.

$\left[\mathrm{NH}_{3}\right]_{\mathrm{T}}$ being the total concentration of ammonia

Rearrangement of this equation of this equation yields

$$
\begin{aligned}
& \log _{10} \frac{\left[\mathrm{NH}_{3}\right]}{\left[\mathrm{NH}_{3}\right]_{T}-\left[\mathrm{NH}_{3}\right]} \\
& =p H-\left[0.09018+\frac{2729.92}{(273.2+\mathrm{T})}\right]
\end{aligned}
$$

Statistical analysis of the study results was performed with "Minitab Release 17 for Windows" software. In terms of water parameters statistical significance between experimental groups were evaluated by one-way analysis of variance (ANOVA) and mean were compared using Fisher's range test at the $5 \%$ level of significance (Zaire 2010).

\section{Results}

Before the addition of zeolite to the experiments $\mathrm{pH}$, temperature, dissolved oxygen, ammonia, and TAN values were found to be approximately $7.81,20.5^{\circ} \mathrm{C}, 7.4 \mathrm{mg} / 1,0.31 \mathrm{mg} / \mathrm{l}$ and $12 \mathrm{mg} / \mathrm{l}$, respectively $(\mathrm{P}>0.05)$.

When the data obtained in this study were evaluated, it was found that the amount of ammonium removal by zeolite increased with decreasing adsorbent size and increasing adsorbent dosage in treatment. The $\mathrm{pH}$ was influenced during the experiment because of a slightly of increase in all the samples (approximately 7.81 before mixing with zeolite). TAN, $\mathrm{NH}_{3}, \mathrm{pH}$ and dissolved $\mathrm{O}_{2}$ values were presented in Table 2. In Table 2 all treatment groups were determined each other for different particle size and adsorbent dosage to statistically $(\mathrm{P}<0.05)$.

Table 2. $\mathrm{TAN}, \mathrm{NH}_{3}$, temperature, $\mathrm{pH}$ and dissolved $\mathrm{O}_{2}$ values in groups at the end of the experiments in three different amounts and two different particle sizes of zeolite $($ mean $\pm \mathrm{SE})$

\begin{tabular}{lccccc}
\hline & \multicolumn{5}{c}{ Water Parameters } \\
\hline \multicolumn{1}{c}{ Trial Groups } & TAN & $\mathrm{NH}_{3}$ & $\mathrm{~T}\left({ }^{\circ} \mathrm{C}\right)$ & $\mathrm{pH}$ & Dissolved $_{2}$ \\
\hline $0.075 \mathrm{~mm}$ Zeolite* & $9.68 \pm 0.27^{\mathrm{c}}$ & $0.28 \pm 0.01^{\mathrm{c}}$ & $20.62 \pm 0.02$ & $7.86 \pm 0.00^{\mathrm{ab}}$ & $7.45 \pm 0.01$ \\
$0.075 \mathrm{~mm}$ Zeolite** & $8.71 \pm 0.30^{\mathrm{d}}$ & $0.25 \pm 0.01^{\mathrm{d}}$ & $20.60 \pm 0.02$ & $7.86 \pm 0.01^{\mathrm{a}}$ & $7.44 \pm 0.01$ \\
$0.075 \mathrm{~mm}$ Zeolite*** & $7.99 \pm 0.35^{\mathrm{e}}$ & $0.23 \pm 0.01^{\mathrm{e}}$ & $20.58 \pm 0.03$ & $7.86 \pm 0.01^{\mathrm{a}}$ & $7.44 \pm 0.01$ \\
$3-5 \mathrm{~mm}$ Zeolite $^{*}$ & $11.49 \pm 0.08^{\mathrm{a}}$ & $0.32 \pm 0.00^{\mathrm{a}}$ & $20.62 \pm 0.01$ & $7.84 \pm 0.00^{\mathrm{b}}$ & $7.43 \pm 0.01$ \\
$3-5 \mathrm{~mm}$ Zeolite** & $10.82 \pm 0.13^{\mathrm{b}}$ & $0.30 \pm 0.00^{\mathrm{b}}$ & $20.57 \pm 0.02$ & $7.85 \pm 0.01^{\mathrm{b}}$ & $7.44 \pm 0.01$ \\
$3-5 \mathrm{~mm}$ Zeolite*** & $10.83 \pm 0.13^{\mathrm{b}}$ & $0.31 \pm 0.00^{\mathrm{b}}$ & $20.60 \pm 0.02$ & $7.85 \pm 0.01^{\mathrm{ab}}$ & $7.45 \pm 0.01$ \\
\hline
\end{tabular}

$* 5 \mathrm{~g} / \mathrm{l}, * * 10 \mathrm{~g} / \mathrm{l}, * * * 15 \mathrm{~g} / \mathrm{l}$, Means with different letter as superscript are significantly different in columns $(\mathrm{P}<0.05)$

In the study, it was determined that the ammonium removal efficiency was stabilized at in 330 minutes. It was found that the $\mathrm{TAN}, \mathrm{NH}_{3}$ concentrations and $\mathrm{pH}$ values were significantly different $(\mathrm{P}<0.05)$, while temperature and dissolved oxygen values were nonsignificant $(\mathrm{P}>0.05)$ for trial groups. Ammonium removal efficiencies (\%) of trial groups were given in Figure 2. 


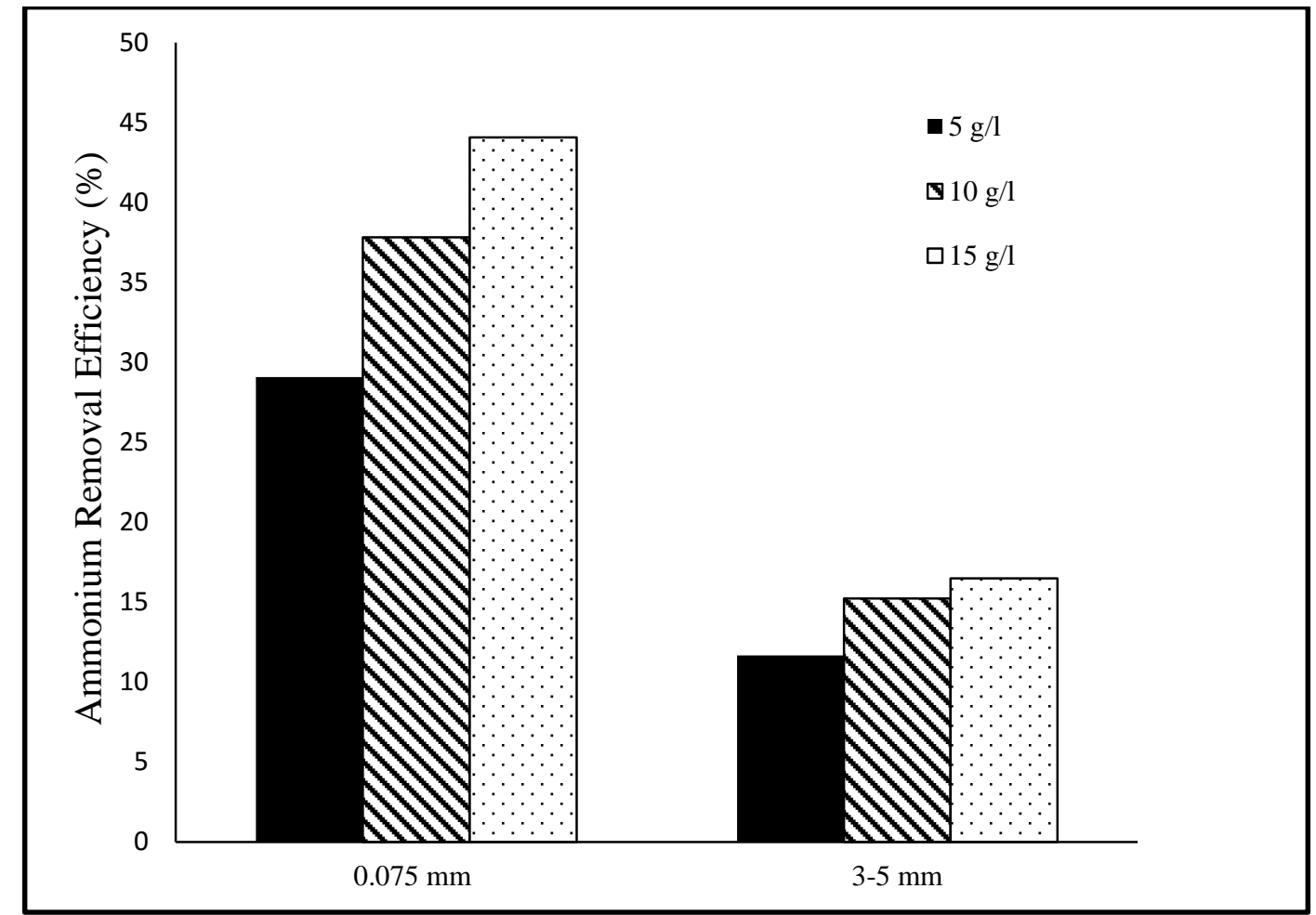

Figure 2. Ammonium removal efficiency (\%) of clinoptilolite added groups in three different amounts and two different particle sizes at the end of the experiment.

As shown in Figure2, the effects of the particle size and amount of adsorbent for the removal of $\mathrm{NH}_{4}^{+}$ ion. The best ammonium removal efficiency was determined at $15 \mathrm{~g} / \mathrm{l}$ and $0.075 \mathrm{~mm}$ as $44.1 \%$. Also, the low ammonium efficiency fixed $11.7 \%$ for $3-5$ $\mathrm{mm}$ and $5 \mathrm{~g} / \mathrm{l}$ (Figure 3).

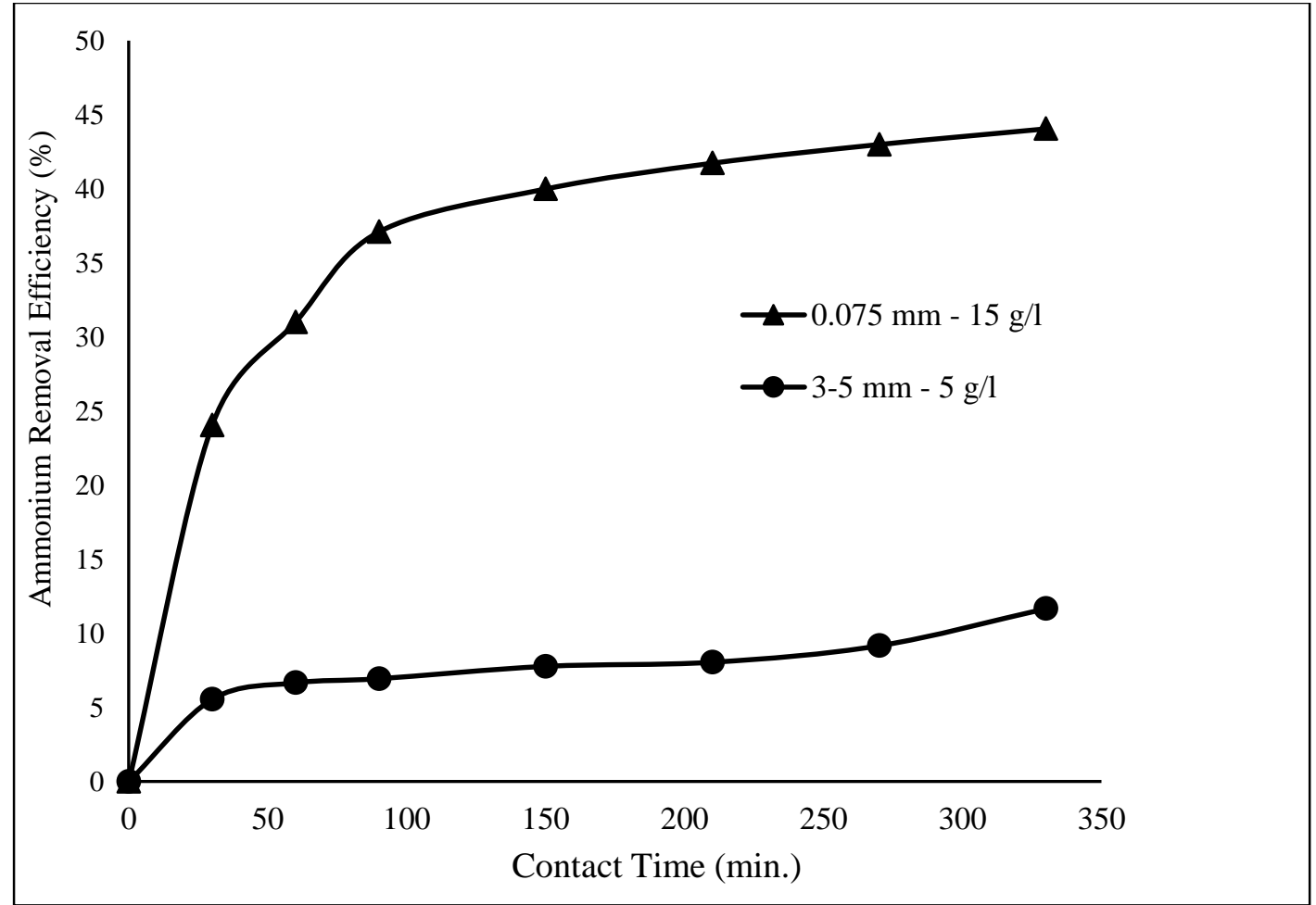

Figure 3. The $\mathrm{NH}_{4}{ }^{+}$removal efficiency according to contact time of zeolite for low and high efficiency groups during the 330 min. at $\mathrm{pH} 7.81,20.5^{\circ} \mathrm{C}$. 


\section{Discussion}

Ammonia is mainly produced through amino acid catabolism in fishes. Ingested proteins are hydrolyzed to amino acids, and the catabolism of excess amino acids leads to the release of ammonia. Aquatic organisms keep body ammonia levels low by excreting the ammonia produced through digestion and metabolism but this waste ammonia released into the water has a toxic effect on the limiting values depending on the species of aquatic organisms. Because of this situation, ammonia in the water should be kept under control. For this control, we used adsorption process with zeolite. Zeolite is an influential and low-cost as alternative adsorbent for the removal of $\mathrm{NH}_{4}{ }^{+}-\mathrm{N}$ from aquatic solution.

It was determined that removal efficiency increasing processes were mostly performed in the previous studies. The capacity of ammonium removal is affected by $\mathrm{pH}$, temperature, reaction time, initial concentration, precondition to adsorbent and shaking speed. $\mathrm{pH}$ values for aquaculture vary from 6.5 to 8.5 (Taş et al. 2010). The highest increase in $\mathrm{pH}$ values determined in this study was in the group of $0.075 \mathrm{~mm}$ zeolite. $\mathrm{pH}$ of solution increases after mixing with zeolite because of calcium and magnesium carbonate compounds hydrolyze (Mazeikiene et al. 2008; Ismadji et al. 2016).

When efficiency increasing processes were applied such as initial ammonium concentration, preconditioning process and shaking speed, the efficiency varies was changed between $80-90 \%$ (Saltalı et al. 2007; Karadağ et al. 2006; Demir et al. 2002). Our study and Alshameri et al. (2014)'s study similarly showed that low initial concentration and without agitation-preconditioning were in the range of $38-81 \%$. In the next studies, zeolite which is natural adsorbents will be modified for planing to be higher ammonium removal efficiency.

The investigation was carried out by using natural zeolite and it was determined that the amount of ammonium removal increased with decreasing adsorbent size and increasing adsorbent dosage in treatment. Comparison of experimental investigation results of two particle sizes of ammonia removal from wastewater shows that $0.075 \mathrm{~mm}$ size is higher efficiency than 3-5 $\mathrm{mm}$ particle size. This indicates that the smaller particle size has a higher ionexchange capacity due to greater available surface area (Demir et al. 2002). This result was found to be similar to the results of the study on the effects of zeolite on the removal of ammonia from Mazeikiene et al. (2008).

In order to research the effect of adsorbent dosage on removal efficiency of $\mathrm{NH}_{4}^{+}$, the experiment was conducted with dosage for $5 \mathrm{~g} / \mathrm{l}, 10 \mathrm{~g} / \mathrm{l}, 15 \mathrm{~g} / \mathrm{l}$. It has been found that the ammonium removal increases as the amount of adsorbent increases in two different sizes like Zabochnicka-Swiatek and Malinska (2010)'s study.

Evaluating to the experimental values, zeolite (clinoptilolite) had a good adsorption performance for $\mathrm{NH}_{4}^{+}$removal from aqueous solution to aquaculture conditions.

\section{Acknowledgements}

We would like to express our appreciation to the company, Rota Mining Company for providing us with the trial material zeolite.

\section{References}

Alshameri A, Yan C, Alani Y, Dawood AS, Ibrahim A. Zhou C, Wang H. 2014. An investigation into the adsorption removal of ammonium by salt activated Chinese (Hulaodu) natural zeolite: Kinetics, isotherms, and thermodynamics. J Taiwan Inst Chem E. 45(2):554-564. doi: 10.1016/j.jtice.2013.05.008

Alshameri A, He H, Zhu J, X1 Y, Zhu R, Ma L, Tao Q. 2017. Adsorption of ammonium by different natural clay minerals: Characterization, kinetics and adsorption isotherms. Appl Clay Sci. 159:83-93. doi: 10.1016/j.clay.2017.11.007

Aydın Temel F, Kuleyin A. 2016. Ammonium removal from landfill leachate using natural zeolite: kinetic, equilibrium, and thermodynamic studies. Desalin Water Treat. 57(50):23873-23892. doi: 10.1080/19443994.2015.1136964

Bock G. 2016. Removal of high and low levels of ammonium from industrial wastewaters [Master's Thesis]. University of Nevada. $82 \mathrm{p}$.

Chow CWK, Davey DE, Mulcahy DE. 1997. An intelligent sensor system for the determination of ammonia using flow injection analysis. Laboratory Automation and Information Management. 33(1):17-27. doi: 10.1016/S1381-141X(97)00004-X

Demir A, Gunay A, Debik E. 2002. Ammonium removal from aqueous solution by ion-exchange using packed bed natural zeolite. Water SA. 28(3):329-336.

Emerson K, Russo RC, Lunt RE, Thurston RV. 1975. Aqueous ammonia equilibrium calculations: effect of $\mathrm{pH}$ and temperature. J Fish Res Board Can. 32(12):2379-2383. doi: 10.1139/f75-274

EPA 1999. United States Environmental Protection Agency. Ambient water quality criteria for ammonia; [cited $2018 \mathrm{Feb} 18$ ]. Available from https://nepis.epa.gov/Exe/ZyPDF.cgi/20003O3L.PDF?Do ckey=20003O3L.PDF

Ghiasi F, Jasour MS. 2012. The Effects of Natural Zeolite (Clinoptilolte) on Water Quality, Growth Performance and Nutritional Parameters of fresh water aquarium fish, Angel (Pterophyllum scalare). International Journal of Research in Fisheries and Aquaculture. 2(3):22-25. 
Gierak A, Lazarska I. 2017. Adsorption of nitrate, nitrite, and ammonium ions on carbon adsorbents. Adsorption Science and Technology. 35(7-8):721-727. doi: 10.1177/0263617417708085

Inglezakis VJ. 2005. The concept of "capacity", in zeolite ion-exchange systems. J Colloid Interf Sci. 281(1):68-79. doi: 10.1016/j.jcis.2004.08.082

Iskander AL, Khald EM, Sheta AS. 2014. Zinc and manganese sorption behavior by natural zeolite and bentonite. Annals of Agricultural Science. 56(1):43-48.

doi: 10.1016/j.aoas.2011.05.002

Ismadji S, Shentong D, Soetaredj FE, Ayucitra A, Yu WH, Zhou CH. 2016. Bentonite hydrochar composite for removal of ammonium from Koi fish tank. Appl Clay Sci. 119:146-154. doi: 10.1016/j.clay.2015.08.022

Jorgensen TC. 2002. Removal of ammonia from wastewater by ion exchange in the presence of organic compounds [Master's Thesis]. University of Canterbury Christchurch. 174 p.

Kammerer J, Carle R, Kammer DR. 2011. Adsorption and Ion Exchange: Basic Principles and Their Application in Food Processing. J Agr Food Chem. 59(1):22-42. doi: 10.1021/jf1032203

Karadağ D, Koç Y, Turan M, Armağan B. 2006. Removal of ammonium ion from aqueous solution using Turkish Clinoptilolite. J Hazard Mater. 136(3):604-609. doi: $10.1016 /$ j.jhazmat.2005.12.042

Mazeikiene A, Valentukevicien M, Rimeik M, Matuzevicius AB, Dauknys R. 2008. Removal of nitrates and ammonium ions from water using natural sorbent:zeolites (clinoptilolite). J Environ Eng Landsc. 16(1):38-44.

doi: 10.3846/1648-6897.2008.16.38-44
Nicolae CG, Sava SC, Marin MP, Pogurschi E, Sava BA. 2017. Innovative solutions for removing nitrogen compounds from water of recirculating aquaculture systems using clinoptilolite natural zeolites. Current Trends in Natural Sciences. 6(11):105-109.

Oluwaseyi AM. 2016. Application of dietary bentonite clay as feed additive on feed quality, water quality and production performance of African catfish (Clarias gariepinus) [PhD Thesis]. Stellenbosch University. $193 \mathrm{p}$.

Öz M, Sahin D, Aral O. 2010. Using of the natural zeolite clinoptilolite in transportation of fingerling trout (Oncorynchus mykiss, W., 1792). Journal of FisheriesSciences.com. 4 (3):264-268. doi: 10.3153/jfscom.2010028

Öz M, Sahin D, Aral O. 2015. The effect of natural zeolite clinoptilolite on aquarium water conditions. Hacettepe Journal of Biology and Chemical. 44(2):205-208. doi: 10.15671/HJBC.20164418130

Prajapati S. 2014. Cation exchange for ammonia removal from wastewater [Master's Thesis]. Tampere University of Technology. $82 \mathrm{p}$.

Saltalı K, Sarı A, Aydın M. 2007. Removal of Ammonium ion from aqueous solution by natural Turkish (Y1ldizeli) zeolite for environmental quality. J Hazard Mater. 14(1):258-263. doi: 10.1016/j.jhazmat.2006.06.124

Taş B, Candan AY, Can Ö, Topkara S. 2010. Ulugöl (Ordu)'ün Bazı Fiziko-Kimyasal Özellikleri. Journal of FisheriesSciences.com 4(3):254-263. doi: 10.3153/jfscom.2010027

Zabochnicka-Swiatek M, Malinska K. 2010. Removal of ammonia by clinoptilolite. Global Nest J. 12(3):256-261.

Zar JH. 2010. Biostatistical Analysis, Books a la Carte Edition (5th Edition). United State of America: Pearson $960 \mathrm{p}$. 